\title{
Identifying Motivators for the Employees in Companies in Bosnia and Herzegovina
}

\author{
Rahimić Zijada, Kožo Amra \\ School of Economics and Business in Sarajevo, Department for Management and Organization, \\ Trg oslobođenja Alija Izetbegović 1, 71000 Sarajevo \\ School of Economics and Business in Sarajevo, Department for Management and Organization
}

Trg oslobođenja Alija Izetbegović 1, 71000 Sarajevo

\begin{abstract}
Competence ability, and even company survival in today's dynamic and relatively unpredictable global business environment, are both becoming increasingly dependent on knowledge, skills and employee competence, as well as their work motivation. Thus, in these times of harsh competition, companies seek ways through which to increase employee readiness to fulfill company goals. Individuals are pushed for action by different motivators, awards and stimulations, all of which mirror their wishes. The task of every manager is to use motivators in order to stimulate employee performance, or drive them to complete their duties. The aim of this paper is to identify those factors that have a motivating effect on the employees working in companies across Bosnia and Herzegovina. The research included workers from different organizations in order to establish a relationship between organizational characteristics and the motivating effects of various factors. The methodological framework of this work has its basis in Herzberg's Two Factor Theory of Motivation. A special challenge for the empirical research, conducted through surveys distributed across companies in Bosnia and Herzegovina, was the identification of motivators which stimulate employee action. The results of this research could help managers in finding answers to different strategies of employee motivation, as well as in increasing their own capability in motivating workers and employing inventive motivators.
\end{abstract}

\section{Indexing terms/Keywords}

Motivators, motivational systems, employees

\section{Academic Discipline And Sub-Disciplines}

Management, Human Resource Management

\section{SUBJECT CLASSIFICATION}

Human Resource Management

\section{TYPE (METHOD/APPROACH)}

This paper provides empirical research in companies in Bosnia and Herzegovina.

\section{Council for Innovative Research}

Peer Review Research Publishing System

\section{Journal of Social Science Research}

\author{
Vol.2, No.2 \\ editor@ijssronline.com \\ www.cirworld.com, www.ijssronline.com
}




\section{INTRODUCTION}

Present-day competitive market conditions imply that almost all companies must seek to motivate their employees, and increase their readiness (loyalty) to meet organizational goals. For managers, this entails additional motivation of workers, a responsibility which often comes on top of their traditional duties. Employee motivation is essential for company efficiency, but also its efficacy. On the other hand, employee motivation is a managerial process which influences human behavior on the basis of knowing what precise factors cause specific human reactions (Wiehrich and Koontz, 1994). What this means is that the motivational system of a company, as well as a sum of all motivators, contribute to the level of interest that employees show towards increasing or maintaining their work results. Furthermore, both of these factors contribute to employee loyalty and their intention to remain in the company (Gmuer and Thommen, 2007). Hence, it can be concluded that management's ability to use various motivators in order to keep its workers and obtain the best possible results for the company itself, are indispensible for long-term company sustainability and success (Loffing et al., 2006).

Managers must keep in mind that motivation is influenced by numerous factors, among which it is important to single out the following: individual characteristics, workplace characteristics and company characteristics. Moreover, external factors (such as living standards, socio-economic development, etc.) also influence individual employee motivation. For example, a difficult economic situation in the country, along with high unemployment rates, will have different effects on an individual's behavior than they would during times of prosperity. In order to create an effective and efficient motivation system, managers can use theoretical knowledge, but also the result of numerous empirical researches.

It is precisely for this reason that the first part of this work will introduce different theories of motivation, with a special focus on the Theory of Needs. Since the aim is to underline the importance of this topic, the authors will also offer an overview of current research that deals with the effects of motivation and the influence that they have on company success. We will also list all the identified motivators. The second part of this work aims at examining the most important motivators in companies across Bosnia and Herzegovina. Finally, the paper will analyze the differences that exist between different motivators in relations to employee gender, age, level of education and years of professional experience.

\section{Theoretical Framework}

Motivational theories try to explain the evolution, direction, power and duration of specific behavior in relations to motives that are relevant for that type of behavior. Different theories of motivation list between two to twenty basic motivators. We usually differentiate between primary and secondary motivators, where the former deal with satisfying basic human physiological needs (hunger, tiredness, etc.), and the latter consider psychological or psycho- sociological motives, such as achieving results, level of power and closeness to other people. The first theoretical explanations of human behavior within the business environment can be found in the early works of Darwin and Freud. According to Darwin, human behavior is influenced by genetically-borne factors, which are mainly directed towards survival. On the other hand, Freud is notable for his claims that there are significant differences between conscious and unconscious human behavior (Bechtel et al., 2010).

The birth of the very concept of motivational theory goes back to the 1930 s, which emerged as a counter movement to Taylorism. Mechanical and harsh observations of human behavior within the business environment that were typical of Taylorism were soon replaced by realizations that humans are socially motivated individuals, notably when in group (Steinmann, 2005). A significant contribution in this period was given by Elton Mayo, who is considered to be the creator of 
the human relations model, and Mc Gregor and his X and $Y$ theories (Stoner and Gilbert, 2002). In the 1950s, we observe an intensive development of the so called „content theories "or „theories of needs“, which explain the relationship and the effect that a specific need has on human action and behavior. The most famous theories of needs include: Maslow's Hierarchy of Needs (Maslow, 1954), Herzberg's Two Factor Theory (Herzberg et al, 1959), Alderfer's ERG Theory (Alderfer, 1972) and McClelland's Achievement of Motivation Theory (McClelland, 1961). Considering that needs are numerous in quantity and diverse in nature, all authors group needs into different categories. Maslow, for example, categorized needs into five different groups, according to urgency of each need and the urgency to satisfy it. Physiological needs, as well as needs that deal with one's security and social status, are lower level needs. On the other hand, needs such as self-assurance and respect are considered to be higher level needs. Herzberg calls these lower level needs the "hygiene factors". These needs include salaries, workplace conditions, interpersonal relations (with bosses, subordinates and colleagues), as well as private life, social status, job security, management and company policies. Herzberg believes that if these factors are missing, there will surely be some dissatisfaction. However, the existence of these factors does not contribute to motivation and employee satisfaction. The second group of factors includes the so called motivators, which include achievement, acknowledgement, challenging tasks, responsibility, career advancement and growth. If these factors exist, there will also exist satisfaction and employee motivation (or absence of satisfaction). However, dissatisfaction cannot exist if these factors are present. Later on, there was a period of cognitive movement which characterized all research conducted on the issue of motivation. This period also saw a certain step back in focusing solely on motives or needs as such; instead, the accent was put on the process of motivation (or better, a question of which thought contributes to certain workplace behavior). Thus, it can be said that cognitive theories try to explain the process of individual decision-making. Much of the literature in this field covers four basic theories of motivation, depending on the way in which individuals are motivated to work more. We can differentiate between the following ones: theory of expectations, theory of amplification, theory of justice and goal-setting theory (Šehić and Rahimić, 2006).

This work focuses on factors that were identified by third parties, with the aim of motivating an individual to exert a certain behavior. Intrinsic motivation begins with self-identified factors, which individuals choose themselves (Mueller, 2011). Alfie Kohn argues that managers must be familiar with the process of intrinsic motivation, in order to better motivate their employees (Bruce and Pepitone, 2001). On the other hand, Sprenger (2007) and Kohn (1999) demonstrate a negative relationship between extrinsic motivators and intrinsically motivated results. Sprenger (2007) believes that motivating destroys motivation. Kohn (1999) relies upon many other studies and researches which show that extrinsic systems of awarding change individual opinions on real tasks - the focus is on the award and intrinsic motivation is lost.

\section{Literature and Research Review}

In today's world, motivation is a subject of numerous researches. This is due to the fact that human resources represent the most important resource an organization can have, and that motivated employees are expected to obtain better results and perform their tasks more readily. Research has been trying to identify the circumstances under which employees agree to work more. On the other hand, research has also tried to find an answer to the question of whether money is the deciding factor in motivating people to obtain better results, or are there other more important factors?

According to the results of a wide-scope research conducted in Germany in 2008 (which included 3.400 persons who ranked 23 different factors, on a scale from one to five), the examinees stated that the most important factor is workplace satisfaction, followed by pleasant working environment (good interpersonal relations) and the ability to perform independently. The first three factors were followed (with significantly lower marks) by job security, ability to realize personal goals and challenging tasks. Since job security is an important motivator, the fear of losing a job (notably in 
today's crippling economy), does to not contribute to excellent results. It was also noted that there were no significant differences between answers provided by men and women, in terms of the most important motivators. However, there are differences between high ranking managers and ordinary employees. It was concluded that work climate is less important to managers, as well as job security. The latter is especially important to younger workers (less than 25 years old) and older employees (more than 50 years old). What is also important to note, is that these factors have just a slight influence on motivation. Here, we can include the desire for excellence, workplace status and control of other employees. It is especially worrisome to note that factors such as "identification with company goals and company image" were ranked fairly low. Only $12 \%$ of employees outside of management believe that identification with the company is very important, while $5 \%$ stated that company image is the most essential factor. The research also concluded that salaries have very little significance for motivation. Men ranked this factor number 11, while women ranked it even lower, on the 13th place. Thus, money alone is not a sufficient factor to be considered as the only motivator (Al-Baghdadi, 2009).

Taking into account the differences that exist between managers and employees in terms of motivators, managers have a challenging task when it comes to applying motivators that are important to their employees. A research conducted among 600 managers from a dozen firms confirms the above statement. During this research, managers had to identify factors that influence motivation and emotions of their employees. Five factors were offered: recognition, financial stimulation (awards), personal support, career advancement and clear goals. Recognition of good performance (public or private) was ranked number one by most managers. Unfortunately, these research results could not be reconfirmed, since the same group of authors conducted a separate research among employees, and discovered that they are mostly motivated by career advancement opportunities (Amabile and Kramer, 2010).

In 2001, a consultancy company named Gallup conducted a research on the topic of employee motivation. The study (Gallup, 2007) emphasized the importance of emotional connectedness of employees to the company, a factor which consequently increases productivity by $18 \%$ (Gallup, 2007). Employees who have low levels of connectedness with their workplace, as well as employees who have no connectedness whatsoever, on average tend to miss two to four workdays per year. Thus, companies that employ more than 1000 people have additional costs which amount up to 485.000 Euros per annum. However, this study does not provide any guidelines on how to successfully invest in human capital, in order to have employees who are dedicated to their workplace. According to Gallup's research (2009), employees who are emotionally connected to their company (13\%) are also dedicated and loyal to it. Two-thirds of all employees have low levels of emotional connectedness to the organization, are not loyal to it and would leave the organization in case they were offered a better opportunity. The rest of the examinees (20\%) show negative attitude towards their workplace, but every third examinee would remain in the company. This decision cannot calm managers, and it simply means that there exist no career advancement perspectives (Gallup, 2009). In 2008, Martin identified factors which contribute to employees' decision to leave their company (Martin, 2011). The research included 1650 experts and managers, and concluded that those factors primarily include issues such as unfair relations, emotional closeness to the employer, current status and future perspectives. Emotional closeness to the employer and workplace satisfaction were the highest among those who manage directly. Another research, which included 3500 examinees, confirmed that „employee satisfaction with his/her boss" directly influences job satisfaction. Up to $40 \%$ of satisfaction was explained by this factor, according to a public communiqué issued by Ruhr University Bochum on August 17, 2009 (Bechtel et al., 2010).

The motivational system must be adjusted according to different types of workers. It is only in this case that employees will be more motivated, achieve better results, stay loyal to their employer, take fewer sick leaves, quit their jobs less frequently and feel better, overall (Truss and Soane, 2010). Nevertheless, the question of whether there is a need to motivate employees during periods of high unemployment is posed quite often. Also, it is necessary to take into account the demographic changes in the society (such as changes in age structure, low number of highly qualified and educated 
youth). Factors such as these can make it hard for companies to find experts in certain fields, once the economic situation improves (Lebrenz and Regnet, 2009). During difficult times, companies that are recognized as preferable employers and that have outstanding „employer branding” have an absolute advantage. Exceptional workers and those who posses special skills and knowledge soon find good business alternatives. Furthermore, the survival and development of all organizations, notably those that operate in complex and challenging fields, depend on workplace loyalty or better employee motivation.

\section{IDENTIFYING MOTIVATORS AMONG EMPLOYEES IN BOSNIA AND HERZEGOVINA}

Modern companies can use multiple factors in the process of generating high levels of motivation and employee loyalty. On the other hand, if these factors are missing, a company will have to face poorly motivated, undedicated employees who are not devoted to performing their everyday tasks. Setting-up an organization which will bring satisfaction to managers, employees and clients is one of the key objectives of all modern organizations. The aim of this research is to identify those factors that contribute to motivation and employee satisfaction in companies in Bosnia and Herzegovina. Furthermore, this research will pinpoint the differences between motivators in different companies. A detailed analysis will try to answer the question of whether there is any difference in motivators when it comes to age, gender, education levels and years of experience. Taking into account the subject and the objectives of the research, we propose the following hypothesis:

$\mathrm{H} 1$ : Characteristics of an organization (according to sector) directly influence the importance of different motivation factors.

H2: The importance of motivators differs according to examinees' age, gender, level of education and years of experience.

\section{The Demographic Structure of the Examinees}

Data acquisition in companies across Bosnia and Herzegovina was conducted in 2010, using the method of survey questions. The sample includes 124 examinees, most of which are employed in the non-profit sector (government, statefinanced), followed by the non-governmental sector (24\%), and lastly by profit organizations (13\%). For the purpose of this analysis, we refer to the non-profit sector in the context of organizations supported by state budget (government sector), while the non-governmental sector (which is also considered non-profit in the context of profit determination) is examined separately. The justification for this lies in the fact that the state of Bosnia and Herzegovina employs the highest number of people. As far as examinees' gender, the data acquired is satisfactory (47\% male and $53 \%$ female). When it comes to education levels, most examinees have university or alternative degrees (86\%). Only $8 \%$ of examinees have only high school degrees, while examinees with master or doctoral degrees are represented by $6 \%$. Most examinees are between 37 to 45 years old (41.94\%), while only $26.61 \%$ of all examinees are between 46 to 60 years old (more in Figure 1 ). 


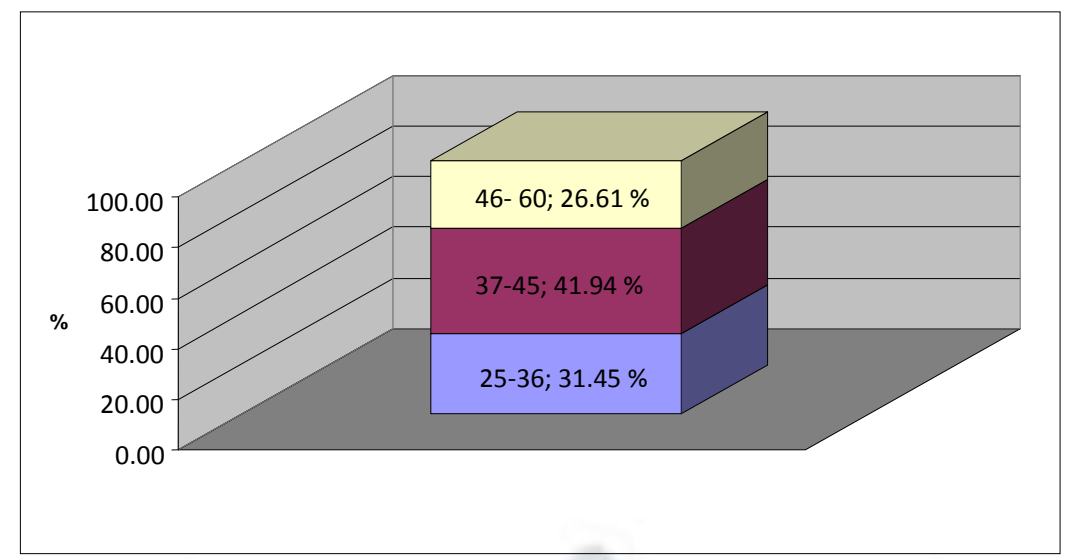

Figure 1. Examinees' age structure

When looking at the years of service spent in a single organization examined, the largest number of examinees fell under the category of „11 to 20 years of service“ (43\%), while the smallest number of examines fell under the interval of „under 5 years" (15\%). When examining the years of service of examinees who worked at the examined organization at the time of research, the largest number of examines was from category „3 to 5 years of service“ (36\%), while the lowest number of examinees fell under the category of „less than 2 years“ (Table 1 ).

Table 1. Years of service of the examinee

\begin{tabular}{cccc}
\hline YEARS OF SERVICE & PERCENTAGE & $\begin{array}{c}\text { YEARS OF SERVICE IN THE } \\
\text { ORGANIZATION IN WHICH THE } \\
\text { EMPLOYEE WORKED DURING } \\
\text { RESEARCH }\end{array}$ & PERCENTAGE \\
\hline UP TO 5 YEARS & $15 \%$ & UP TO 2 YEARS & $15 \%$ \\
$6-10$ YEARS & $21 \%$ & $3-5$ YEARS & $36 \%$ \\
$11-20$ YEARS & $43 \%$ & $6-10$ YEARS & $27 \%$ \\
$>20$ YEARS & $21 \%$ & OVER 10 YEARS & $22 \%$ \\
\hline
\end{tabular}

Source: Authors' calculation

\section{The Results of Empirical Research}

The interviewees marked the importance of motivators according to their personal opinion on a scale from one to five (1 not important at all, 5 - very important). The total number of motivator factors was twenty, for which creation we used Herzberg's classification of motivator factors. We also took into consideration the characteristics of business environment in Bosnia and Herzegovina. Since this was a wide research, one of our research goals was to identify the importance of education and career development as motivator factors for those employed in companies across Bosnia and Herzegovina. As it can be noted from the table, the examinees pay special attention to salary levels (4.77). The fact that standard deviation is 0.5821 demonstrates that there are no significant oscillations in examinees' answers. More precisely, this motivator ranks number one in both, the non-profit (4.86) and non-governmental sectors (4.60), while the examinees from the profit sector ranked it second (4.69), only after quality of workplace conditions (4.75). It is also important to note that regular salaries, according to theories of motivation, are considered basic motivational factors (e.g. Maslow's theory 
places it on the bottom of the pyramid in the group of physiological needs, while Herzberg's theory calls this factor a hygienic factor which does not motivate workers, but can cause dissatisfaction and poor motivation).

Table 2. Motivator ranks, sample comparison according to organization type

\begin{tabular}{|c|c|c|c|c|c|c|}
\hline \multirow[b]{2}{*}{ RANKS } & \multirow[b]{2}{*}{ MOTIVATORS } & \multicolumn{2}{|c|}{$\begin{array}{l}\text { FULL } \\
\text { SAMPLE }\end{array}$} & \multirow{2}{*}{$\begin{array}{c}\text { NON- } \\
\text { PROFIT } \\
\text { ORGS. } \\
\text { AV. } \\
\text { GRADE }\end{array}$} & \multirow{2}{*}{$\begin{array}{l}\text { NGO } \\
\text { SECTOR } \\
\text { AV. } \\
\text { GRADE }\end{array}$} & \multirow{2}{*}{$\begin{array}{l}\text { PROFIT } \\
\text { ORGS. } \\
\text { AV. } \\
\text { GRADE }\end{array}$} \\
\hline & & $\begin{array}{l}\text { AV. } \\
\text { GRADE }\end{array}$ & $\begin{array}{l}\text { STAND. } \\
\text { DEV. }\end{array}$ & & & \\
\hline 1. & REGULAR SALARY & 4,77 & 0,5821 & 4,86 & 4,60 & 4,69 \\
\hline 2. & RELATIONS WITH THE SUBORDINATES & 4,14 & 0,8700 & 4,16 & 4,07 & 4,19 \\
\hline 3. & $\begin{array}{c}\text { THE IMPORTANCE OF BUSINESS FOR THE } \\
\text { COMMUNITY }\end{array}$ & 3,92 & 0,9508 & 3,87 & 4,10 & 3,81 \\
\hline 4. & QUALITY OF WORK CONDITIONS & 3,90 & 1,0155 & 3,78 & 3,77 & 4,75 \\
\hline 5. & JOB STABILITY AND SECURITY & 3,81 & 1,1311 & 3,91 & 3,47 & 3,94 \\
\hline 6. & TECHNICAL SUPPORT & 3,78 & 1,0403 & 3,64 & 3,80 & 4,44 \\
\hline 7. & RELATIONS WITH SENIOR MANAGEMENT & 3,73 & 1,0920 & 3,73 & 3,70 & 3,75 \\
\hline 8. & SALARY RATE & 3,63 & 0,9519 & 3,64 & 3,67 & 3,56 \\
\hline 9. & $\begin{array}{c}\text { INTERPERSONAL RELATIONS WITHIN } \\
\text { COMPANY }\end{array}$ & 3,58 & 1,1050 & 3,56 & 3,43 & 3,94 \\
\hline 10. & $\begin{array}{c}\text { DEGREE TO WHICH YOUR SALARY COVERS } \\
\text { YOUR PERSONAL COSTS }\end{array}$ & 3,57 & 0,9809 & 3,55 & 3,50 & 3,81 \\
\hline 11. & SOCIAL STATUS GAINED THROUGH WORK & 3,53 & 0,9494 & 3,50 & 3,63 & 3,50 \\
\hline 12. & $\begin{array}{l}\text { LEVEL OF RESPONSIBILITY, FREEDOM OF } \\
\text { DECISION-MAKING, WORK AUTONOMY }\end{array}$ & 3,48 & 1,0080 & 3,31 & 3,73 & 3,88 \\
\hline 13. & POSSIBILITIES FOR CREATIVE WORK & 3,46 & 1,1645 & 3,22 & 3,6 & 4,38 \\
\hline 14. & $\begin{array}{c}\text { POSSIBILITIES FOR WORK } \\
\text { ACCOUNTABILITY AND PERFORMANCE } \\
\text { RESULTS OF ALL EMPLOYEES WITHIN THE } \\
\text { DEPARTMENT }\end{array}$ & 3,46 & 1,0469 & 3,55 & 3,47 & 3,0 \\
\hline 15. & $\begin{array}{c}\text { POSSIBILITY FOR CAREER DEVELOPMENT } \\
\text { AND SPECIALIZATION WHICH THE } \\
\text { ORGANIZATION OFFERS TO ITS } \\
\text { EMPLOYEES }\end{array}$ & 3,36 & 1,2187 & 3,28 & 3,03 & 4,38 \\
\hline 16. & $\begin{array}{l}\text { REGULAR FEEDBACK ON INDIVIDUAL } \\
\text { PERFORMANCE AND WORK QUALITY }\end{array}$ & 3,17 & 1,1314 & 3,15 & 3,43 & 2,75 \\
\hline 17. & CAREER ADVANCEMENT POSSIBILITIES & 2,93 & 1,2505 & 2,71 & 3,07 & 3,75 \\
\hline 18. & FREE-TIME & 2,87 & 1,1331 & 2,82 & 3,07 & 2,75 \\
\hline 19. & $\begin{array}{l}\text { POSSIBILITY TO SAVE MONEY OR PAY LIFE } \\
\text { INSURANCE }\end{array}$ & 2,85 & 1,2881 & 2,73 & 2,83 & 3,44 \\
\hline 20. & $\begin{array}{c}\text { POSSIBILITY OF FLEXIBLE WORKING } \\
\text { HOURS }\end{array}$ & 2,59 & 1,3369 & 2,51 & 2,97 & 2,31 \\
\hline
\end{tabular}

It is interesting to note that "regular or timely payments" were ranked higher than the actual "salary rate" which was ranked eight. Number five was taken by "job security and workplace stability". The importance given to these factors can be explained by organizational characteristics, as well as the current situation, but most importantly the fact that most companies in Bosnia and Herzegovina follow negative business trends, struggle for mere survival and are not able to pay their employees on regular basis. Besides this, the current situation on the job market, high unemployment rates, average wage rates and the level of living standards all contribute to the importance of certain motivators. For example, in February 2011 the average consumer basket for a family of four members was $1.750 \mathrm{KM}$, out of which $708 \mathrm{KM}$ had to be paid for food (www.manager.ba accessed 25. 08. 2011). 
Table 3. Employment, unemployment and average net salaries per capita in FB\&H (www.fzs.ba accessed 25. 07. 2012)

\begin{tabular}{cccccc}
\hline & & & & & JUNE \\
& 2008 & 2009 & 2010 & 2011 & 2012 \\
\hline $\begin{array}{c}\text { TOTAL NUMBER OF } \\
\text { EMPLOYEES } \\
\text { TOTAL NUMER OF } \\
\begin{array}{c}\text { UNEMPLOYED } \\
\text { AVERAGE NET SALARIES }\end{array}\end{array}$ & 430.745 & 437.501 & 438.949 & 440.747 & 439.094 \\
PER CAPITA & 338.643 & 354.577 & 364.929 & 367.515 & 372.266 \\
\hline
\end{tabular}

The results show that relations with the subordinates are ranked exceptionally high in all three sectors, with average grades of 4.16, 4.07 and 4.19, respectively. The placement of individual motivator categories further depends on the type of organization, so the non-profit sector singles out five most important motivators, which include (aside from regular payments) relations with subordinates, job security and stability, the importance of the job for a wider community and quality of workplace conditions. On the other hand, non-governmental sector (also aside from regular payments) singles out the importance of the job for a wider community, relations with subordinates, technical support and quality of workplace conditions. Lastly, the profit sector focuses on quality of workplace conditions, regular payments, technical support, possibilities for additional education which the organization offers to its employees, and possibility for creative work. Thus, we can see that all motivators are closely related to the type of the sector, as well as the nature of work (including the importance it has for a wider community, which was marked second by the non-governmental sector, confirming the mission and primary goals of business conduct in the non-governmental sector). On the other hand, the possibility for further specialization and creative work are the basic generators of business conduct in the profit sector.

The employees in Bosnia and Herzegovina's companies are least motivated by the following factors: the possibility for career advancement (with the organization), possibility for savings or investments in a form of life insurance and flexible working hours (average grade was less than 3). However, standard deviation is slightly higher when it comes to different types of organizations, ranging from 1.1331 (free time) to 1.3369 (flexible working hours). Flexible working hours are ranked lowest in non-profit (2.51) and profit (2.51) sectors, while in the non-governmental sector this factor was placed $19^{\text {th }}$, with an average grade of 2.97. Hence, according to Herzberg, these factors (aside from free time) are motivator factors. This means that employees in Bosnia and Herzegovina are motivated by hygiene factors. Subsequently, according to Maslow's hierarchy of needs, lower level needs are dominant.

Using the Kruskal-Wallis Test, it was verified whether there were any statistically significant differences between the observed types of organizations, notably in terms of ranking certain motivators. Statistically significant difference between the interviewees coming from various organizations exists when it comes to these motivators: Quality of work conditions; technical support; level of responsibility, freedom of decision-making, work autonomy; possibilities for creative work; possibility for career development and specialization which the organization offers to its employees and career advancement possibilities (values of $P$ are less than 0.05).

Table 4. Overview of the interdependence of motivators and organization types

\begin{tabular}{ccc}
\hline MOTIVATORS & CHI- & P VALUE \\
& SQUARED & \\
\hline QUALITY OF WORK CONDITIONS & 15,3504 & 0,0005 \\
TECHNICAL SUPPORT & 8,5293 & 0,0141 \\
LEVEL OF RESPONSIBILITY, FREEDOM OF DECISION- & 6,0813 & 0,0478 \\
MAKING, WORK AUTONOMY & & \\
\hline
\end{tabular}




\begin{tabular}{ccc}
\hline POSSIBILITIES FOR CREATIVE WORK & 14,9845 & 0,0006 \\
POSSIBILITY FOR CAREER DEVELOPMENT AND & 14,5939 & 0,0007 \\
SPECIALIZATION WHICH THE ORGANIZATION OFFERS TO & & \\
$\quad$ ITS EMPLOYEES & & \\
CAREER ADVANCEMENT POSSIBILITIES & 10,1970 & 0,0061 \\
\hline
\end{tabular}

\section{Source: Author's calculations}

Quality of workplace conditions is especially important to those employed in the profit sector (profit organizations) (4.75), where this factor ranks number one. Both the non-profit and non-governmental sectors rank this factor fifth (3.78 and 3.77 respectively). The picture is similar when it comes to technical support for work, which profit organizations placed third (4.44), while the non-profit ranked it seventh (3.64) and non-governmental sector fourth (3.80). Considering a specific nature of organizations, as well as uncertainty and turbulence of today's business environment, along with fierce competition between employees, it is not wrong to conclude that the quality of workplace conditions and technical support are essential. Thanks to these factors, the employees in the profit sector are able to react both faster and better to changes in the business environment and meet customer expectations. In order to fulfill their customers' wishes and expectations and build long-lasting relationships based on loyalty, factors such as "level of responsibility, freedom in decision-making" and "individual work" are essential in this sector (average grade of 3.86). This motivator is also important for the non-governmental sector, where most activities are project-based and dependent on team work, along with decentralization and responsibility that affects most employees (average grade 3.73). Unlike profit and non-governmental sectors, the non-profit sector (state institutions) has a rigid and well-defined organizational structure, with clear and precise workplace descriptions, both of which significantly undermine the importance of factors such as "levels of responsibility", "freedom in decision-making" and "individual work" (rank $13^{\text {th }}$, with an average grade of 3.31). The employees are well aware of their job characteristics, and the possibility they have for advancement, thus ranking this motivational factor relatively high. For the same reason, state officials rank creative work relatively low (3.78), placing it only on the $15^{\text {th }}$ place. The possibility for creative work in the profit sector (profit organizations) is extremely important, and thus ranks fifth with an average grade of 4.38 . This is because creativity contributes to reaching and maintaining market competitiveness. Although we believe that creativity is important for success in the non-governmental sector, the examinees from these companies ranked it only $10^{\text {th }}(3.60)$.

What is especially troublesome for long-term success of companies in Bosnia and Herzegovina, is the fact that, looking at the whole sample, creativity ranks $13^{\text {th }}$, while additional education and specialization rank $15^{\text {th }}$. The situation is even worse when it comes to career advancement opportunities within the organization, a factor that was ranked as low as $17^{\text {th }}$. Possibilities for further specialization is most important for employees coming from profit organizations (average grade is $4.38,4^{\text {th }}$ place), while this motivator is least important to those employed in the non-governmental sector $\left(3.03,18^{\text {th }}\right.$ place). The outcome is similar when looking at career advancement possibilities; it is most important to the employees of profit organizations $\left(3.75,13^{\text {th }}\right.$ place), and least important to non-profit, state-budgeted organizations (state institutions -2.71 , $19^{\text {th }}$ place). These deviations are explainable by very few possibilities for advancement, since the organizational structure of state institutions is very firmly defined and inflexible in comparison to profit organizations, which have a more supple organizational construction.

On the basis of the above analysis (presented through identification of importance placed on motivators), as well as the analysis of motivator interconnectedness across different sectors, using the Kruskal-Wallis Test, we can conclude that the hypothesis: characteristics of an organization directly influence the importance of different motivation factors, is confirmed.

With the aim of establishing a relationship or interconnectedness between the twenty observed motivators, using variables such as gender, age, years of experience and levels of education, the rest of our analysis used non-parametric tests (as a 
result of Kolmogornov-Smirnov test all values of $p$ were less than 0.05 , so we can conclude that the assumption of normality is not satisfied). Using the Kruskal-Wallis Test, it was verified whether there were any statistically significant differences between the observed types of organizations, notably in terms of ranking certain motivators. Statistically significant are all those values of $P$ that are less than 0.05 with a corresponding Kruskal-Wallis one way test. In that case, the hypothesis that the observed samples or groups are statistically different is confirmed.

Table 5. Interdependence between motaviators and examinee's age, years of experience and exeminee's level of education

\begin{tabular}{lccc}
\hline MOTIVATORS & EXAMINEE'S AGE & $\begin{array}{c}\text { YEARS OF } \\
\text { WORKING } \\
\text { EXPERINCE }\end{array}$ & $\begin{array}{c}\text { EXEMINEE'S } \\
\text { LEVEL OF } \\
\text { EDUCATION }\end{array}$ \\
\hline REGULAR/ TIMELY PAYMENTS & & 29,542 & 18,933 \\
A RATE TO WHICH YOUR SALARY & 7,473 & $\mathrm{P}=0,003$ & $\mathrm{P}=0,004$ \\
COVERS YOUR PERSONAL EXPENSES & 17,239 & 22,982 & 2,688 \\
JOB SECURITY AND STABILITY & $\mathrm{P}=0,028$ & $\mathrm{P}=0,114$ & $\mathrm{P}=0,952$ \\
QUALITY OF WORKPLACE CONDITIONS & 2,197 & 20,815 & 19,024 \\
& $\mathrm{P}=0,974$ & $\mathrm{P}=0,186$ & $\mathrm{P}=0,015$ \\
RELATIONS WITH THE BOSS & 6,072 & 21,131 & 16,850 \\
FREEDOM IN DECISION-MAKING AND & $\mathrm{P}=0,639$ & $\mathrm{P}=0,174$ & $\mathrm{P}=0,032$ \\
INDIVIDUAL WORK & 7,059 & 41,903 & 5,035 \\
& $\mathrm{P}=0,530$ & $\mathrm{P}=0,000$ & $\mathrm{P}=0,754$ \\
\hline
\end{tabular}

As we can see from table 5., there is a degree of interdependence between:

1. „examinee's age“ and a grade given to the following motivators: „a rate to which your salary covers your personal expenses" and "level of responsibility, freedom in decision-making and individual work"

2. „years of experience“ and a grade given to: „regular/timely payments“ and „relations with the boss“

3. „Examinee's level of education “and a grade given to „regular/timely payments“, ,job security and stability "and "quality of workplace conditions“.

A statistically significant difference according to Chi-Square Test did not exist between gender and the twenty motivators that were analyzed. Insignificant deviations were recorded by a method of comparison between average grades given by males and females. For example, „job security and stability” is more important to males (3.91) in comparison to females (3.71). This data leads to the inevitable question of whether these results are linked to the traditional belief that men are supposed to subsist their families.

The examinees from different age groups gave different grades to "a rate to which your salary covers your personal expenses". The highest grade was given by examinees that are 46 or older (3.79), while this motivator was least important to examinees who are between 37 and 45 years old (3.44). These grades can partially be explained by career development phases; employees have different priorities when they are rapidly advancing (or when they are in their top form) in their careers, compared to mentorship positions and positions held before retirement. The picture is completely different when it comes to the second motivator, where significant interdependence between age groups was noted. Hence, the oldest examinees give little importance to the "level of responsibility, freedom in decision-making and individual work"(3.39), while the youngest ones rank it relatively higher (3.59). It is assumed that older employees already have higher levels of responsibility and freedom to take initiative, while this motivator is more significant to younger examinees who believe that higher levels of responsibility have a stimulating effect in terms of further career advancement. In addition, younger examinees gave similar answers (standard deviation was 0.880 ). 
Looking at examinees' years of professional experience, „a regular payment” was the most important and best ranked motivator among all categories. However, if we look into more detail, we can notice that this motivator is especially important to those individuals with twenty or more years of professional experience (5.00). Consequently, this motivator is less important to those examinees that have 11 to 20 years of experience (4.80). Interestingly enough, „regular payments“ is least important to employees who are just starting to develop their careers (up to five years of experience, 4.29). Although they gave the grade in comparison to other examinees (in terms of years of experience), this category of examinees also believes that "regular payments" is the most important motivator (it received the highest grade among all other motivators that were ranked by examinees with the least number of years of professional experience). "Relations with senior staff/boss" is most important to second and fourth category of examinees, more precisely to those who have 6 to 10 years of professional experience (4.04), and those that have 21 to 30 years of experience (4.00). These relations are least important to examinees with only a few years of experience (2.88). Moreover, this factor is one of the lowest ranking among all other motivators, being placed $14^{\text {th }}$ out of 20 places.

Examinees with different levels of education, give different grades to the following three motivators: "regular payments", "job security and stability" and "quality of workplace conditions". Although "regular payments" is very pronounced and important for all three categories, the grades differ significantly: high-school education (4.10), university or community college degree (4.83) and masters/doctoral degree (4.88). In principle, the examinees with high school diplomas did not give high grades to all motivators. It is surprising that "job security and stability" was ranked relatively high (4.50) by examinees holding masters/doctoral degrees. In comparison, the same motivator received the lowest grades from examinees with high school diplomas (3.30). This unusual trend can be explained by the fact that there is a relatively small supply of jobs requiring such high levels of academic education. In addition, examinees with the highest level of education (masters or doctoral degrees) consider that "regular payments" is the most important motivator, followed by "quality of workplace conditions" (4.62) and "job security and stability" (4.50). The situation is almost identical when it comes to "quality of workplace conditions". In terms of education levels, this motivator was ranked highest by holders of masters/doctoral degrees (4.62), and lowest by examinees with high-school diplomas (3.30). The results of the above presented analysis on the interconnectedness of motivators and individual characteristics demonstrate that the hypothesis: the importance of motivators differs according to examinees' age, gender, level of education and years of experience, is partially confirmed (since there were no statistically significant differences between gender and the motivators analzyed).

\section{CONCLUSION}

Employee motivation is a deciding factor of success in every organization. Present-day fiercely competitive business environments and demanding customers make it hard for companies to survive. Consequently, the endurance and development of an organization depends on motivated, creative and innovative employees who are dedicated to their work. Motivated and satisfied employees directly contribute to customer satisfaction and loyalty. On the other hand, lack of motivation will yield poor results, low productivity and low revenues. Every employee reacts to different motivators, thus the difference in the levels of motivation. Consequently, managers must recognize which motivators move their employees to work better and take action. Furthermore, managers must know that employee motivation also depends on their individual characters, job and organizational characteristics, as well as outside factors. The results of the research conducted in companies across Bosnia and Herzegovina show that the most important motivator for most employees is "timely payments", which received a grade of 4.77. This confirms the effects of outside factors. High unemployment rates, low living standards, and small supply of attractive jobs in Bosnia and Herzegovina surely have an impact on the rank of this motivator. 
According to Maslow's hierarchy of needs and Herzberg's Two Factor Theory, "regular payments" is basic motivational factor. This motivator received the highest grade from the entire sample, regardless of age, gender, level of education or years of experience. If we look at the type of organization (or sector) to which a company/organization belongs, it can be concluded that "timely payments" was ranked highest in non-profit and non-governmental sectors. In the profit sector, this factor was ranked second. Motivators which are, according to Herzberg's theory, considered motivator factors have significantly lower grades. Aside from "flexible working hours" (2.59), which was ranked lowest, low grades were also given to "career advancement within the organization" (2.92), "possibilities for additional specialization within the organization" (3.36) and "possibilities for creative work" (3.45).

The success of a motivation system also depends on whether there exist any differences in terms of motivators among employees coming from different types of organizations, as well as on factors such as age and gender, years of experience and level of education. Statistically significant differences in grades given by employees working in different types of organizations relate to the following motivators: quality of work conditions; technical support; level of responsibility, freedom of decision-making, work autonomy; possibilities for creative work; possibility for career development and specialization which the organization offers to its employees and career advancement possibilities. In terms of employee character, statistically significant differences (value of $P$ is less than 0.05 ) were noted for six motivators. Two depended on the age group ("levels to which your salary covers your living expenses" and "level of responsibility, independent decision-making and work autonomy), and years of experience ("timely payments" and "relations with the boss"). On the other hand, three motivators depended on the examinees' level of education ("timely payments", "job security and stability" and "quality of work conditions"). Gender did not play an important role in analyzing the above motivators, since it did not show statistically significant differences in answers.

The presented research results show that managers of companies in Bosnia and Herzegovina must focus on the characteristics of the business environment, but more importantly on the organizational characteristics (which depend on the sector, levels of education, age and level in the company hierarchy) in the process of deciding which motivators to employ. In order for a company and its motivation system to succeed, it is essential to keep in mind the different effects that motivators have, depending on the type of service and different categories of employees. 


\section{REFERENCES}

[1] Al-Baghdadi, W. 2009. Was uns motiviert, Harvard Business Manager, 12/09, pp. 22-23.

[2] Alderfer P. Clayton, 1972., Existence, Relatedness and Growth: Human Needs in Organizational Settings, Free Press, New York

[3] Amabile, M. T. and Kramer, J. S., 2010. Was Mitarbeitern wirklich hilft, Harvard Business Manager, 05/10, pp. 36-38.

[4] Bechtel, P., Friedrich, D. and Kerres, A., 2010. Mitarbeitermotivation ist lernbar, Springer, Berlin Heidelberg, pp. 23 36., p.40

[5] Bruce, A. and Pepitone, S.J. 2001., Mitarbeiter motivieren, Campus Verlag, Frankfurt/New York, pp. 16-17.

[6] Federacija BiH u brojkama, Federalni zavod za statistiku, Sarajevo 2012., www.fzs.ba, (accessed 25. 07. 2012)

[7] Gallup Organization, 2009. Engagement-Index 2008. Postdam. www.gallup.de (accessed 20. 07. 2011.)

[8] Gallup, 2007. Gallup Services - Proaktives Handeln in Zeiten der Unsicherheit, Gallup [Internet], http://www.gallup.com/Germany/117457/Gallup-Service-Proaktives _ Handeln-Zeiten-der-Unsicherheit.aspx (accessed 10.06.2009)

[9] Gmuer, M. and Thommen, J-P., 2007. Human Resource Management, Versus Verlag, Zuerich

[10] Herzberg, F., Mausner, B. And Snyderman, B., 1959. Motivation to work, New York, John Wiley and Sons

[11] Kohn, A., 1999. Punished by rewards: the trouble with gold stars, incentive plans, As, price and other bribes, Houghton Mifflin Company, Boston, New York

[12] Lebrenz, C. and Regnet, E., 2009. Wieder nichts gelernt? Vom Umgang mit dem Fachkraeftemangel in Krisenzeiten, Personal 10, pp. 20-23.

[13] Loffing, Ch., Hofmann, C. and Splietker, M. 2006. Mitarbeitermotivation leich gemacht, Kohlhammer Verlag, Stuttgart, p. 13.

[14] Martin, A., 2008. Der Wettbewerb um attraktive Arbeitsplaetze. http://www.hanseatischespersonalkontor.de/presse/pdfs/Hapeko Wettbewerb 2008-15-05-08.pdf (accessed 20. 07. 2011.)

[15] Maslow, A., 1954. Motivation and Personality, New York, Harper\&Row

[16] McClelland C. David, 1961., The Achieving Society, New York, Van Nostrand Reinhold

[17] Mueller, M.: Chancen nutzen in der Krise - motivierte und kreative Mitarbeiter als Erfolgsfaktor http://margitmueller.de/app/download/3453292102/Mitarbeitermotivation.pdf (accessed 25. 04. 2011.)

[18] Sprenger, R.K., 2007. Mythos Motivation. Wege aus einer Sackgasse. 18. Aufl. Campus, Frankfurt

[19] Steinmann, H. andSchreyoegg, G. 2005. Management, Gabler Verlag, Wiesbaden, p. 536.

[20] Stoner, Dž. and Gilbert, D.R., 2002. Menadžment, Zelnid, Beograd

[21] Šehić, Dž and Rahimić, Z. 2006. Menadžment, Ekonomski fakultet u Sarajevu, Sarajevo

[22] Truss, K. and Soane, E. 2010. Fordern Sie die Spielverderber, Motivation III, Harvard Business Manager 05/10, pp. 38-40.

[23] Wiehrich, H. and Koontz, H., 1994. Menadžment, Mate, Zagreb

[24] www.manager.ba 09. March 2011. (accessed 25. 08. 2011.) 